\title{
Compensation for Damages Caused by Nuclear Accidents: A Convention as Insurance
}

\author{
by Michael G. Faure* and Göran Skogh**
}

\section{Introduction ${ }^{1}$}

The rights of a victim of a nuclear accident to be compensated for losses are governed by international conventions. These conventions make the licensee of a nuclear plant strictly liable. However, the maximum amount of compensation is limited and short statutes of limitations apply. The conventions provide that the signatory States should implement a minimum compensation to victims, but, within the limits set by the convention, the States are free to set the maximum amount of compensation. The statutory limits adapted by the signatory States varied in 1988 between US $\$ 6$ million and US $\$ 300$ million. Hence, also the exposure to liability of the licensee of a nuclear plant varies considerably. If the damage exceeds the amount mentioned, the State will have to pay compensation up to a certain limit. If the damage also exceeds that limit, compensation will be paid by all the signatory States up to 300 million IMF Special Drawing Rights.

After the accidents of Harrisburg and Chernobyl it has become clear that the amounts of the various national statutes implementing the conventions are not at all sufficient to cover the damages caused by such an accident. Apparently the statutory limits were too low even to cover relatively small accidents. If an accident would occur e.g. in central Europe, which would cause losses of lives and damages in several countries, serious political and diplomatic controversies may result. Damages to property and real estate may cause large losses for many individuals. Large property owners and especially large creditors, insurance companies, banks or pension funds that have real estate as collateral may suffer immense losses. The existing conventions do not provide adequate compensation for those losses.

In this paper we argue that a new convention could provide better compensation for losses due to nuclear accidents. First we summarize the contents of the conventions and their implementation in several European Countries (2). Then we show in what respect

* Professor, University of Maastricht.

** Professor, University of Lund.

1 We thank Mr. Johannes C. Oudijk and an anonymus referee for useful comments on an earlier draft of this paper. 
the statutes implementing the conventions fail to provide coverage for serious damages caused by nuclear accidents (3). Next, attention will be paid to an optimal regulation of nuclear accidents and it will be discussed in what respect the actual conventions fail to reach an efficient outcome (4). Finally we outline a new convention that could provide compensation and prevention of nuclear accidents more efficiently (5).

\section{Liability for nuclear accidents: the legal situation}

\subsection{The conventions on liability and insurance for nuclear accidents}

Most of the conventions which regulate liability and insurance for damages caused by nuclear accidents originated through the European Nuclear Energy Agency (ENEA) of the Organization for Economic Cooperation and Development (OECD). ${ }^{2}$

The first convention to be mentioned is the Convention of Paris of July 26, 1960. Article 3 of this convention provides that the licensee of a nuclear powerplant is liable for all damage caused to persons and all property damage (with a few exceptions) if it can be proven that the losses are caused by a nuclear accident. Article 6 of the convention of Paris expressly states that a law suit can only be brought against the licensee who is liable according to the provisions of the conventions or, if possible under national law, against the insurer of the licensee. The same article also provides that no one else than the licensee of the nuclear plant will be held liable. This is the so-called 'channelling of liability'. The right of redress of the lincensee against third parties who may be liable to have caused the accident is seriously limited: article 6 (f) provides that recourse is only possible if the third party intentionally caused the harm or if a right of redress was made possible through a contractual arrangement. ${ }^{3}$

Article 7 of the convention of Paris provides that the liability of the licensee shall be limited to $15,000,000$ currency units, but it is left to the law of signatory States to increase or decrease this amount. Article $7 \mathrm{~b}$ expressly mentions that the possibility to get insurance coverage should be taken into account in fixing the amount of liability of the licensee. However, the exposure to liability of the licensee may never be lower than $5,000,000$ currency units.

Article 8 stipulates that the entitlement on compensation lapses if a law suit has not been filed within 10 years after the nuclear accident happened. In addition article 8 allows the national legislation to introduce an additional time bar of two years from the moment that the victime knew the damage, and the identity of the licensee who is liable for the accident. However, also with the introduction of this time bar of two years the first mentioned statute of limitations of 10 years since the accident has happened may also not be passed. Article 8 (c) provides that national legislation can fix a larger term than 10 years if the liability of the licensee is also covered after the 10 years period.

Particularly important is article 10 which provides that the liability according to the convention should be covered by insurance or another kind of guarantee for the amount fixed according to article 7 .

${ }^{2}$ This ENEA has been replaced by the NEA on April 20, 1972, after Japan also became a member of the organisation (See the Introduction to Nuclear Third Party Liability and Insurance, Munich Symposium, Status and Prospects, Paris, OECD, 1985).

${ }^{3}$ All these conventions regulate the liability of the licensee of a nuclear plant; it would also be possible to examine whether under international law the State could be liable for damages caused by a nuclear plant on its territory against a 'victim' State. See Wildhaber 1987. 
This convention of Paris has been complemented by a supplementary Convention of Brussels of January 31, 1963. In article 3 of this Convention of Brussels the signatory States agree to cover losses caused by nuclear accidents to an amount of $120,000,000$ currency units per accidents. The compensation should take place as follows:

- up to $5,000,000$ currency units (the exact amount must be fixed by the legislation of the signatory States) the damages must be covered by the licensee who is liable for the accident and who should have insurance to cover this amount ;

- between the amount to be paid by the (insurance of) the licensee and 70,000,000 currency units the State in which the nuclear powerplant which caused the accident is located, must pay the damages;

- between $70,000,000$ and $120,000,000$ currency units all the signatory States will contribute to the compensation of the damages, according to a division which is provided in article 12 of the Convention of Paris.

In addition to these two conventions the States also agreed to two additional protocols of January 28, 1964, which amended the original conventions. These Protocols were necessary since several initiatives had also been taken by the International Atomic Energy Agency, a specialised UN Agency, located in Vienna. The Protocols of January 28, 1964 were meant to coordinate the Vienna Conventions and the earlier mentioned Conventions of Paris and Brussels. However, the abovementioned principles were not changed by these protocols.

The Convention of Brussels was again amended by two Protocols of Paris of November 16, 1982. One of the consequences of these Protocols was that the maximum amounts of compensation for nuclear damages were changed from currency units to IMF-Special Drawing Rights. The maximum amount of the liability of the licensee was fixed at 15,000,000 Special Drawing Rights. The States can change this amount, but it can never be lower than 5,000,000 Special Drawing Rights. The additional Protocol also changed the amount of the Convention of Brussels into Special Drawing Rights. The maximum amount available for compensation of losses caused by a nuclear accident is now $300,000,000$ Special Drawing Rights. This is the amount up to which all signatory States will intervene according to a division provided in the convention. ${ }^{4}$

\subsection{The implementation of the convention}

It is of course not possible within the scope of this paper to provide a detailed description of all the national legislations which implemented the conventions on liability for nuclear accidents. We will just mention a few examples. One should remind that according to the conventions all States have to introduce strict liability for the licensee of a nuclear powerplant and that some type of compulsory insurance or guarantee for the liability exposure of the licensee must be fixed. But in that respect a lot of freedom is left to the States. Hence, it seems especially interesting to examine how the State statutes regulate the statute of limitations and the amount of damages to be compensated by the licensee. In Belgium the conventions were first implemented by the Act of July 18, 1966. ${ }^{5}$ This Act limited the liability of the licensee of a nuclear plant to 500,000,000 Belgian Francs and compulsory

\footnotetext{
${ }^{4}$ For an overview of these conventions, see Faure/Van den Bergh, 1989, p. 284-287.

${ }^{5}$ Moniteur belge, August 23, 1966.
} 
insurance was introduced. This amount was increased to $1,000,000,000$ Belgian Francs by a Royal Decree of May 13, 1980.6 A new Act was necessary to adapt Belgian law to the new Protocols of November 16, 1982. This Act was promulgated on July 22, 1985. ${ }^{7}$ Article 5 of the Act holds the licensee of a nuclear plant strictly liable for all damage caused by a nuclear accident. The liability is channelled to the licensee: no law suit can be brought against a third liable party and no suit can be brought by the victim against the licensee on other grounds than the Act. Hence, the victim cannot bring a suit anymore on the basis of the common negligence rule of tort law. ${ }^{8}$ The liability of the licensee is now limited to $4,000,000,000$ Belgian Francs. Article 8 of the Act forces the licensee to cover his liability up to the mentioned amount or to provide another kind of guarantee for the payment of the amount. The Belgian Act also takes over the statute of limitations of the Paris Convention: a law suit has to be filed within 10 years after the accident happened and within 3 years from the moment that the victim knew the damage and the identity of the licensee. ${ }^{9}$ The principles are more or less the same in the Netherlands: an Act of 1979 implements the conventions in the Netherlands. ${ }^{10}$ The strict liability is channelled to the licensee of the nuclear plant. The maximum amount of the liability was fixed at 200,000,000 Dutch guilders. ${ }^{11}$ The licensee must insure his liability up to the maximum amount of liability. In addition there is a State guarantee to compensate losses due to a nuclear accident up to $1,000,000,000$ Dutch guilders. ${ }^{12}$

In Germany there also existed a limitation of the liability of the licensee up to an amount of 1,000,000,000 German Marks. This limitation has, however, been abrogated in 1985 and has been replaced by unlimited liability of the licensee. There is a duty for the licensee to seek insurance coverage up to an amount of $200,000,000$ German Marks on the market for commercial insurance and up to $300,000,000$ German Marks with the nuclear insurance pool. The remaining $500,000,000$ German Marks are guaranteed by the German State. ${ }^{13}$

In Sweden the total liability of the plantowner is maximized to $800,000,000$ Swedish Crowns. The State and the convention cover up to a maximum of $3,000,000,000$ Swedish Crowns.

In France the liability of the licensee is limited to $50,000,000$ French Francs and in the United Kingdom the licensee is liable up to an amount of 50,000,000 Pound Sterlings. ${ }^{14}$

${ }^{6}$ Moniteur belge, May 13, 1980.

${ }^{7}$ Moniteur belge, August 31, 1985. For details concerning this Act, see Bocken, 1984, p. 394-396; Cousy, 1974-75, p. 35-51; Dermagne, 1981, p. 665-672; Faure/Van den Bergh, 1989, p. 284-299; Faure/Van den Bergh, 1990.

8 This was made clear during the parliamentary debate in the Senate (Parliamentary proceedings, Senate, 1983-84, 593/3, p. 32-33).

${ }_{9}$ Article 23 of the Act of July 22, 1985.

${ }^{10}$ For details: Robesin, 1987, p. 226-231; Van Maanen, 1986, p. $1342-1345$.

11 Article 3 of the Royal Decree of April 27, 1987.

12 This amount is higher than the amount the State has to contribute according to the conventions. See Van Maanen, 1986, p. 1342.

13 See Van Maanen, 1986, p. 1344.

${ }^{14}$ Robesin, 1987, p. 228. 
The various amounts are brought together in the following table, which shows that the exposure to liability of the licensee of a nuclear plant still varies considerably in different European countries.

\begin{tabular}{ll}
\multicolumn{1}{c}{ Table 1 : } \\
Implementation of the conventions in some countries 15 \\
Country & Amount of liability of the licensee in (US $\$$ ) \\
Belgium & US $\$ 100,000,000$ \\
Netherlands & US $\$ 100,000,000$ \\
Germany & unlimited liability + compulsory insurance for \\
& US $\$ 250,000,000$ \\
Sweden & US $\$ 130,000,000$ \\
France & US $\$ 10,000,000$ \\
United Kingdom & US $\$ 95,000,000$
\end{tabular}

These limits became highly debated after the Chernobyl accident on April 26, 1986, because it showed that the losses could largely exceed the amount mentioned in the table above. For instance in the Netherlands Van Maanen proposed to increase the liability of the licensee to $1,000,000,000$ Dutch Guilders of which $500,000,000$ were to be insured by the private insurance of the licensee and another $500,000,000$ by the State. In addition the State should compensate for losses caused by nuclear accidents up to an amount of $10,000,000,000$ Dutch guilders. ${ }^{16} \mathrm{He}$ is, however, opposed to unlimited liability. Other authors suggested to increase the amount of the State guarantee and the amount of insurance, but to abrogate the limitation of liability. ${ }^{17}$ After the Dutch legislator increased the amount of liability to $400,000,000$ Dutch Guilders in 1987 a new bill has been introduced to increase the State guarantee to 2,000,000,000 Dutch Guilders. ${ }^{18}$

In Belgium a proposal has been introduced in Parliament by two members of the House of Representatives on November 25, 1986, to make the licensee liable for the damages caused by a nuclear accident, without financial limit, but to limit the duty to insure to an amount of $500,000,000,000$ Belgian Francs. ${ }^{19}$ A newspaper article also mentions a proposal of the Belgian socialist party to increase the financial cap on liability from $4,000,000,000$ Dollars.

15 To make the figures comparable, we have transferred the amounts to an estimation in US

16 Van Maanen, 1986, p. 1344. In March 1991 the government introduced a proposal to amend the statute to increase the limit to 1,000,000,000 Dutch Guilders.

17 Robesin, 1987, p. 231.

18 Bill No. 20374. See on these proposals also Robesin, 1987, p. 230 and Brussard/Drupsteen/ Gilhuis/Koeman, 1989, p. 286-287.

19 Parliamentary Proceedings, House of Representatives, 1986-87, 402/1. 
to $7,000,000,000$ Belgian Francs. This proposal is obviously more modest than the first one mentioned. 20

\section{The costs of a nuclear accident}

The occurrence of new accidents is not at all hypothetical. In a 1986 article, Islam and Lindgren estimated that with the then existing nuclear powerplants ( 374 in the whole world) there is a $86 \%$ probability that a new nuclear accident will occur within the next 10 years (or $70 \%$ that it occurs within the following 5.4 years). And they assume that from 1986 on no powerplant will be built. ${ }^{21}$ It is therefore most important to examine whether losses caused by a nuclear accident, e.g. in central Europe, could be covered within the existing statutory limitations.

An indication of the potential costs of a nuclear accident is given in the Sandia Siting Study of 1982 (also called the Sandia Report). ${ }^{22}$ The study examined the consequences of an accident that could happen in any of the American nuclear powerplants. The study makes a distinction between an accident with 'average' consequences and a large accident. The only costs measured are the costs of deaths, injured and potential cancer-cases and the property damage. They come to the following results: ${ }^{23}$

Table 2:

Costs of a nuclear accident according to the Sandia Report (millions of dollars)

1. Average accident :

- 700 to 1,300 deaths on the spot

$-2,400$ to 5,000 injured

- 7,600 to 9,300 potential cancer cases

deaths

$5 \times 700$ to $1,300=$

$3,500 \quad 6,500$

injured

$0.1 \times 2,400$ to $5,000=$

500

cancer cases

$1 \times 7,600$ to $9,300=$

Subtotal

property damage

\begin{tabular}{rr}
7,600 & 9,300 \\
\hline 11,340 & 16,300 \\
10,000 & 10,000
\end{tabular}

Total

$21,340 \quad 16,300$

20 "SP wil hogere aansprakelijkheid voor nucleaire rampen", De Morgen, November 13, 1987.

21 Islam/Lindgren, 1986.

22 The results of this study are also summarized in the appendix of a Belgian proposal to increase the insured amount substantially (Parliamentary Proceedings, Belgian Senate, 1986-87, 402/1, p. 6-7) and in a proposed amendment to the Belgian Act of July 22, 1985 (Parliamentary Proceedings, Belgian Senate, 1983-84, 593/4, p. 2).

23 This study was ordered by the Nuclear Regulatory Commission, an American federal agency for nuclear energy. As a result of this study, the NRC proposed an amendment of the Price Anderson Act regulating liability for nuclear accidents in the US in order to increase the amount of liability up to $160,000,000$ US $\$$. 


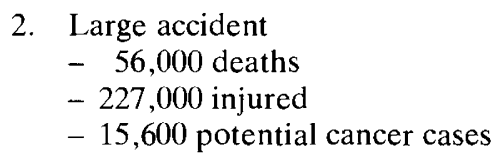

deaths

\begin{tabular}{lr}
$5 \times 56,000=$ & 283,000 \\
injured & \\
$0.1 \times 227,000=$ & 22,700 \\
cancer & \\
$1 \times 15,600=$ & 15,600 \\
Subtotal & 321,300 \\
\hline Property damage & 374,000 \\
Total & 695,000
\end{tabular}

If one compares these numbers to the amounts of (insured) liability mentioned in table 1 it needs no further discussion that these amounts can in no way cover the losses caused by a nuclear accident, not even of a small 'average' accident.

If one looks at the estimates of the costs of the nuclear accidents that already occurred, it seems that the amounts given in table 1 were not sufficient to cover the losses. For the Three Miles Island accident of March 28, 1979, insurers reported that they had to pay 29 million US $\$$ up to June 1983 . The amount the insurers paid covers only a part of the losses and gives no indication of the total social costs of the accident. Evans and Hope show that there are a lot of hidden costs of the accident at Three Miles Island. The direct costs of the clean-up operation were estimated at 975 to 1034 million US \$. But in addition to these costs also the costs of writing off what was essentially a new reactor should be taken into account. The figure involved is somewhere in the range of 1,000-3,000 million US $\$ .^{24}$

A more serious accident happened on April 26, 1986, in Chernobyl. Press reports give some indication of the costs of this accident. 250 persons died as direct result of the accident ; in an area of $30 \mathrm{~km}$ around the plant 135,000 persons had to be evacuated and after 3 years 600,000 persons had complained of health problems due to exposure to radiation. The direct loss caused by the accident is estimated at $15,000,000,000$ US $\$$, only in the Soviet Union. But the effects were also felt outside Russia. For instance in Norway between 1987 and $198930 \%$ of all cattle was contaminated through radioactive exposure. ${ }^{25} \mathrm{~A}$ more detailed description of the costs of Chernobyl is given by Medvedev. He pays attention to the impact of the accident on the environment, on agriculture, the health impact in the Soviet

\footnotetext{
${ }^{24}$ For other details concerning the problems with estimating the costs of a nuclear accident, see Evans/Hope, 1984, p. 74-98.

25 See Morrens, 1990, p. 14-15.
} 
Union and the global impact. ${ }^{26}$ The study provides an interesting overview of the Chernobyl accident which easily justifies the conclusion that the total costs of this accident largely exceed the insured amounts mentioned in table 1.27

Some preliminary conclusions may be drawn from this experience. First, we cannot neglect the possibility of a new accident, in central Europe, or anywhere else in the world. A possible accident of a size somewhere between the Three Mile Islands and the Chernobyl accident may cause large damage, especially if the ground and/or the air is contaminated by radiation. However, the number of immediate fatalities may not be as large as estimated in table 2. The reason is that most people in the surroundings of an accident can move before they are killed by radiation. Long-term radiation is more problematic. The radiation may cause cancer and other diseases far away from the plant. The costs are difficult to estimate, partly because the diseases may be influenced by many inter-dependent factors. It may therefore be impossible to identify a single cause.

Second, the compensation to victims will be unsatisfactory. Health-care and income losses may be covered by private, first party insurance and/or social insurance, e. g. lifeinsurance, public health care, disability insurance and pension schemes. Property damages will, in contrast, to a large extent be uncovered by insurance and the international conventions. An accident that makes an abandonment of the area around a plant necessary may cause immense losses of land and property.

A nuclear accident in e.g. central Europe may destroy land or property in surrounding nations. Serious diplomatic controversies may arise. Individuals as well as large estate owners (such as insurance companies and pension funds) are likely to suffer large losses. The effect on the financial system is often overlooked. Since most credits are guaranteed by real estate a lot of creditors will not recover their loans. The consequence can be the bankruptcy of many financial institutions, which may disturb the international financial system.

Some part of the responsibility may be taken over by the State and it will probably provide for some compensation over the limits of State compensation in the existing conventions. The impact on public budgets may therefore be large. Since not all the losses will be compensated the distribution of the available compensation will be a political matter. Certain groups, for instance individuals who go bankrupt and have to move as a result of the accident, may receive some coverage for their losses, while the compensation to large estate owners and creditors might be uncertain.

\section{Optimal liability and safety-regulation}

\subsection{Strict liability}

The limited compensation in case of a nuclear accident does not only result in serious consequences for the victims. It may also result in sub-optimal prevention of accidents. Much attention has been spent in the Law and Economics literature on optimal legal mechanisms to prevent accidents. Here we briefly point out some relevant results.

A general result is that strict and unlimited liability may be optimal under certain assumptions. Strict liability prevails when the injurer (plant-owner) is liable for all losses

\footnotetext{
${ }^{26}$ Medvedev, 1990. Compare: Haynes/Bojcun, 1988 and Marples, 1988.

${ }^{27}$ It should not be forgotten, however, that the Soviet Union is not a party of the conventions. But the discussion of the Chernobyl accident is interesting to show that the costs of an average nuclear accident may largely exceed the insured amount available to compensate losses.
} 
due to an accident. Optimal care is found when the marginal benefits of accident reduction equal the marginal costs of care. The level of care may be referred to as $Y$, where $Y$ is a vector: $Y 1, Y 2 \ldots Y n$ of all control variables. Examples of control variables are the dimension of the hull of the plant, the length of tubes in the cooling system, the number of safety checks, and the activity level of the plant. The optimal care level, $Y^{*}$, is thus reached when all the various control measures are at a level where the marginal cost of control equals the benefit in terms of accident reduction. ${ }^{28}$

For optimality under strict liability the liable party must be able to influence the risk by precautions, either directly or indirectly by contracts with parties able to influence the risk. This assumption is, in large, fulfilled for the nuclear firm. A nuclear accident is a result of the activities within the plant. Moreover, it is sudden and the impact (at least the immediate damage) can be identified.

A second assumption is that the liable party is a rational profit-maximizing (risk-neutral) agent. It is also assumed that the liable injurer will fulfil the obligations. Hence, there is no bankruptcy problem or other obstacle that limits the collectable amount in case of an accident. If these assumptions are fulfilled, it is in the self-interest of the injurer to choose the vector $Y^{*}$ of optimal controls.

From the description above it is obvious that the limited assets of the liable plantowner may result in a bankruptcy. That will cause moral hazard and free-rider problems. ${ }^{29}$ Large claims are of minor economic interest to the firm because they cannot be collected. The industry will thus not take optimal care freely.

The problem of limited collectable assets may partly be reduced by mandatory liability insurance. However, to be accepted on the insurance market the insurer must, at least to some extent, be able to control the behaviour of the insured. Otherwise insurance will contribute to moral hazard. Insurers normally control the insured in different ways. One is by regulation via conditions in the policy. Another is by pricing of precautions, deductibles and bonuses. ${ }^{30}$ However, such measures require that the insurer is informed of the benefit of various controls. Large number actuarial information is needed, but such is absent because of the small number of accidents. That might explain why losses of billions of dollars are hard, if not impossible, to insure on the international insurance market.

\subsection{Negligence}

If a negligence rule is applied, the injurer (plant-owner) will only have to pay compensation if he choses to take less care than the legal system wants him to (due care). Given that due care is equal to the efficient level of all controls, $Y^{*}$, the injurer will have an incentive to take all the efficient controls to avoid liability. ${ }^{31}$

Hence, if the courts aim at optimal care and know all optimal controls, negligence may be as optimal as strict liability. A problem is, of course, that the courts do not have all the information needed. Moreover, controls like the activity level may not be incorporated in the due care standard. ${ }^{32}$

\footnotetext{
28 See Shavell 1980; Shavell 1987.

29 See Shavell 1986.

30) See Shavell 1979.

31 See Adams 1985 ; Cooter 1982 ; Shavell 1980.

32 See Diamond 1974; Faure/Van den Bergh 1989.
} 
Another shortcoming is that victims will not be compensated. The injurer is motivated to take due care to avoid to have to pay compensation to victims. The injurer will therefore usually not pay damages. Persons may be protected by social insurance and first party health- and life-insurance. The nuclear industry may cover its property losses by property insurance. However, third party property owners cannot protect themselves by first party insurance. Nuclear accidents are usually excluded in the property insurance policies.

\subsection{Safety regulation}

The regulation of care could also be achieved by public safety regulation. In this case a public regulatory body decides on safety measures and quantitative restrictions of nuclear investments and production methods. The given norms may be controlled by inspection, and enforced by various penalties. ${ }^{33}$

For care to be optimal, the authorities must know $Y^{*}$ which, of course, is a strong assumption. The publicly available information on nuclear safety and production is most limited. The public authorities are therefore dependent on information from the industry. The information given by the industry may be biased, however. The authorities, and the public, that distrust the industry may thus be unwilling to follow all advices given by the industry. Complementary independent information is demanded, but the available information is poor. The regulation may therefore be arbitrary with too much regulation in some respects, and too little in others. In countries with a strong opinion against nuclear power the industry may be forced to make investments although the impact on safety may be negligible, while other control measures may be disregarded.

Another shortcoming is that safety-regulation does not contribute to the compensation of victims. ${ }^{34}$

\section{A new convention}

Some authors have, as mentioned above, argued in favour of strict liability with higher limits of liability (or unlimited liability) for plant-owners. The argument is that the industry, that is best informed of the risks, shall also be responsible and have the full economic incentive to take care.

Strict liability may have, as noted above, a comparative advantage as a mechanism for the control and compensation of accidents. An important obstacle in the case of nuclear accidents is, however, that the liability level where bankruptcy and/or uninsurability becomes a reality is soon reached. This is already the case in Germany where liability in principle is unlimited, but in practice the liability is limited due to the limits of insurability.

With unlimited liability and full insurance coverage the potential claims may come up to, say US $\$ 100$ billion. The insurance industry cannot accept such risks. A reason is that the experience of accidents, and thus the actuarial information is too limited. The industry is unable to draw up adequate policies, and to price the various risks and precautions. It is also impossible for the reinsurance industry to accept the huge risks.

Note, however, that the uninsurability of large risks in the insurance market does not mean that large risks cannot be shared by ex ante agreements. Risksharing agreements for risks that cannot be covered by an established insurance industry (that supply policies at premiums fixed ex ante) are common both in history and today. Roman syndicates as well

\footnotetext{
33 See Skogh 1982.

34 See Hansson/Skogh 1987.
} 
as modern joint-ventures and indemnity clubs, for e.g. the liability of oil pollution, are such agreements. Typical of such agreements is that the risk is uncertain and maybe impossible to estimate, at least at the start, before large number information is available. A market with the sale of policies with premiums fixed ex ante requires much large number experience.

In fact, the existing conventions on liability for nuclear accidents favour such risksharing agreements. However, the conventions have only been slightly modified since the 1960s. The experience of nuclear accidents, and the fact that the liability cannot be insured on the market make it necessary (i) to increase the limit of liability and (ii) to solve the risksharing, which can be done on a state level.

The risk-sharing needs to be realized through an international convention. First, the damage is of a size and nature that it presumably causes conflicts among States. Second, States are large enough to share and reinsure the large risks involved.

The convention would gain from being world-wide. More realistic, however, (at least in the short run) is to try to establish an extended convention in EC and EFTA nations. As an example we outline a convention including the following points:

1. The owner of a nuclear powerplant is strictly liable for losses caused by an accident, including third party liability. So far there is no change as compared to today's conventions.

2. In principle, the liability is unlimited. Initially, before the convention is established in large parts of the world, it may be necessary to limit the liability to, say US $\$ 100$ billion, which is about 100 times the size of the liability today (including commitments of States).

For minor and medium size accidents this level is high enough, at least for property losses. Social insurance, private health, life-insurance and pension schemes will to some extent compensate for health care costs and income losses due to long-term radiation.

3. A key issue is to solve the bankruptcy/insurance problem. Otherwise compensations will remain small in practice. A possible solution is a paragraph that stipulates that the plantowner has to be a member of a mutual guarantee-fund, including the plant-owners in the signatory States. The mutual pool covers the liability in case of an accident. Assume, for instance, that there are 100 nuclear plants in the signatory States, and thus 100 members of the nuclear risksharing fund. Assume further that the maximum liability of US $\$ 100$ billion is to be covered in case of an accident. Each plant-owner has then to contribute one billion dollars. Hence, a maximum guarantee of one billion dollars for each plant-owner in case of an accident in any of the plants in the pool would cover all possible claims

4. The large potential claims on each plant and the possibility of an accident including more than one plant, makes reinsurance necessary. A fraction of the desired coverage might be provided by the international insurance market. It is therefore reasonable that States reinsure the liability of the plants in their own country. Such an agreement ought to be possible, because States are often co-owners of the nuclear plants. Already, the States cover losses of the plants in their country up to a level of half a billion dollars.

The suggested size of the guarantee, and thus the potential liability of the plant-owners and the States is about the same as it is today. The difference is that all plants share the costs of accidents wherever they occur in signatory States. Assume, for instance, that there is an accident in France that causes damages of US $\$ 60$ billion in France, Belgium and Germany. Each of the 100 plant-owners will then contribute 600 million dollars. For instance, the 
twelve plants in Sweden would have to cover 7.2 billion dollars of the losses. However, most of these costs would be reinsured by the Swedish State and to some extent covered by the international insurance market.

Today, the economic liability of plant-owners is most limited (see table 1). Larger damages are covered by States, or arbitrary spread by victims. The plant-owner has therefore an economic incentive to prevent small accidents in the first place. There is no collective economic responsibility for the industry. Hence a serious externality prevails, and thus a rationale for political pressure, public control and heavy safety regulation. Maybe the most important effect of the convention is that it would reduce the externality and the political pressure. First, unlimited liability of the plant-owner reduces the externality to a level set by bankruptcy. Second, liability over this level is to a large part transferred from the single plant owner to a collective guarantee-fund mutually owned by the nuclear power industry in the signatory States. As insurer, the mutual fund will face a moral hazard and adverse selection problem. It will therefore be in the interest of the mutual fund to control its members and to reduce risks, for instance by requirements for being accepted as a member (and thus allowed to start up power production). As potential claims vary largely with the density of population around the plant, and the construction of the plant, there will immediately be a discussion within the industry on safety measures, different guaranteeamounts and/or premiums for different plants. Although the experience of nuclear accidents is most limited, there is substantial knowledge on risks and potential losses within the industry which can be used in its internal control and pricing. Hence the industry will freely take preventive measures and put a price, although incomplete, on the risks of nuclear power.

The industry will not cover all potential damages, however. Parts will be covered by first party insurances, social insurances and by victims. A large part will be reinsured by signatory States. An externality will therefore remain, and so will the demand for political control and safety regulation. The basis for political pressure and public regulation will be reduced, however, if the industry takes the economic responsibility we suggest. Political failures due to sudden opinions, poorly informed politicians etc., will presumably be reduced by a convention. This is not only of public interest, but also of interest to the industry. A convention may reduce hostility towards, and fear of, nuclear power and technical progress in general.

\section{Summary and final remarks}

Today we have strict, but limited, liability in case of a nuclear accident. The Three Mile Islands and the Chernobyl accidents have made in clear that new accidents with large losses spread about, affecting a number of different countries may occur again.

Health-care and income losses are to a certain degree covered by private first-party insurance and social insurances. Property losses by third parties are excluded, however, in insurance policies. And the international conventions are insufficient to cover large losses. If an area around a plant has to be abandoned, huge property losses may result with random victimization, including disturbances of the financial system and international political conflicts.

The limited liability also causes a free-rider problem in the nuclear industry. The industry is not given strong enough incentives to prevent large accidents. Public safety regulation 
may reduce the accident risk. The authorities are dependent, however, on information from the industry and of political opinions that may make the precautions inoptimally large in some respects, and small in others.

Increased, or unlimited, strict liability would increase the compensation to victims, and the incentives to take care in the industry. A problem is, however, that the level where the nuclear firm goes bankrupt, and where the international insurance market refuses to give coverage, is soon reached.

An extended international convention could, however, improve the situation considerably. To demonstrate this, we present an example of such a convention. The strict liability of a plant-owner is unlimited, or restricted to US $\$ 100$ billion (given that the number of plants in the signatory states is one hundred).

The costs are spread by a mutual guarantee fund set up by the convention. The plantowners are mandatory members of the fund. Each plant-owner has to sign a guarantee of a maximum of one billion dollars in the case of an accident in any of the plants in the member states. With liability limited to US $\$ 100$ billion and 100 plants this is enough to cover all claims. This amount can, like it can today, be reinsured by the State and, to some extent, the insurance market.

The suggested convention is simply an ex ante agreement among States and plantowners on how to distribute costs of potential accidents. An accident today could lead to random victimization, political conflicts and large economic disturbances. An ex ante regulation is not only of public interest, but also of interest to the industry. A convention reduces the public's disutility of risk aversion thus the fear of nuclear power in general.

An important effect of a convention would be that the accident prevention would gain a new economic dimension. Unlimited liability of plant-owners in combination with a mutual guarantee fund will create a collective interest of the industry to reduce risks and to control pool members. This can be done by requirements for being accepted as a member of the pool and by internal pricing of safety-measures.

An opinion in favour of a convention may be established. First, countries without nuclear power have only benefits of the system. Second, countries with nuclear power may have very large losses. It is therefore in the interest of these countries to clarify the liability and to share the costs. Third, there are well-functioning negotiation bodies within OECD, EEC and EFTA that can prepare a convention. A problem may be that the accident risks vary in different countries. Hence there may be disputes on membership, guarantees and fees. However, the safety and the construction of the plants in this part of the world is relatively similar, which simplifies a convention of EEC and EFTA countries. The rest of Europe may join the convention later on. Fourth, economically very strong pressure-groups have much to gain from the convention and the cost-sharing, especially creditors, farmers and insurers with a lot of real estate in their portfolios. 


\section{REFERENCES}

ADAMS, Michael, Ökonomische Analyse der Gefährdungs- und Verschuldenshaftung, Heidelberg, R. v. Decker's Verlag, 1985.

ADAMS, Michael, "New Activities and the Efficient Liability Rules", in Essays in Law and Economics, Faure, Michael and Van den Bergh, Roger (Eds.), Antwerp, Maklu, 1989, p. 103-106.

BOCKEN, Hubert, "Van fout naar risico. Een overzicht van de objectieve aansprakelijkheidsregelingen naar Belgisch recht, Tijdschrift voor Privaatrecht, 1984, p. 329-415.

BRUSSAARD, W., DRUPSTEEN, Th., GILHUIS, R. and KOEMAN, N. (Ed.), Milieurecht, Zwolle, Tjeenk Willink, 1989.

COOTER, Robert, "Economic Analysis of Punitive Damages", Southern California Law Review, 1982, 79-101.

COUSY, Herman, "Een nieuwe vorm van schuldloze aansprakelijkheid. Aansprakelijkheid voor schade veroorzaakt door het vreedzaam gebruik van kernenergie", Jura Falconis, 1974-75, p. $35-51$

DERMAGNE, Jean-Marie, "La responsabilité civile nucléaire. Aperçu du droit applicable aux accidents d'origine nucléaire et à la reparation des dommages causés par de tels accidents", Journal des Tribunaux, 1981, p. 665-672.

DIAMOND, Peter, “Single Activity Accidents", Journal of Legal Studies, 1974, p. 107-164.

EVANS, Nigel and HOPE, Chris, Nuclear Power. Futures, Costs and Benefits, Cambridge, Cambridge University Press, 1984.

FAURE, Michael and VAN DEN BERGH, Roger, Objectieve aansprakelijkheid, verplichte verzekering en veiligheidsregulering, Antwerpen, Maklu, 1989.

FAURE, Michael and VAN DEN BERGH, Roger, "Liability for Nuclear Accidents in Belgium from an Interest Group Perspective, International Review of Law and Economics, 1990, p. 241-254.

FAURE, Michael and HEINE, Gunter, "The insurance of Fines: the Case of Oil Pollution. The Geneva Papers on Risk and Insurance, 1991, p. 39-58.

HAMBURGER, Marty, "De aansprakelijkheidsverzekering in Nederland voor schade door kernongevallen in West-Europa", Nederlands Juristenblad, 1986, p. 1335-1341.

HAYNES, Viktor and BOJCUN, Marko, The Chernobyl Disaster, London, Hogarth Press, 1988.

HANSSON, Ingmar and SKOGH, Göran, "Moral Hazard and Safety Regulation", The Geneva Papers on Risk and Insurance, 1987, p. 132-144.

ISLAM, S. and LINDGREN, K., "How many reactor accidents will there be?", Nature, 21, August 1986.

MARPLES, David, The Social Impact of the Chernobyl Disaster, London, MacMillan 1988.

MEDVEDEV, Zhorer, The legacy of Chernobyl, New York, Norton, 1990.

MORRENS, Paul, De Golf en de zwemmer. Bedenkingen bij de leefmilieuproblematiek, Antwerp, Standaard, 1990.

ROBESIN, M., “Aansprakelijkheid voor kernongevallen, ruim een jaar na Tsjernobyl”, Milieu en Recht, 1987, p. 226-231.

SHAVELL, Steven, "On Moral Hazard and Insurance", Quarterly Journal of Economics, 1979, p. $541-562$. 
SHAVELL, Steven, "Strict Liability versus Negligence", Journal of Legal Studies, 1980, p. 125.

SHAVELL, Steven, "Liability for Harm versus Regulation of Safety", Journal of Legal Studies, 1984, p. 357-374.

SHAVELL, Steven, "The Judgement Proof Problem", International Review of Law and Economics, 1986 , p. $45-58$.

SHAVELL, Steven, Economic Analysis of Accident Law, Harvard, Cambridge University Press, 1987.

SKOGH, Göran, "Public Insurance and Accident Prevention", International Review of Law and Economics, 1982 , p. 67-80.

SKOGH, Göran, "The Combination of Private and Public Regulation of Safety", in Essays in Law and Economics, Faure, Michael and Van den Bergh, Roger (Eds.), Antwerp, Maklu, 1989, p. 87-101.

SKOGH, Göran, "The Transactions Cost Theory of Insurance, Contract Impediments and Costs", The Journal of Risk and Insurance, 1989, p. 726-732.

VAN MAANEN, G., "Pleidooi voor verbetering van de rechtspositie van slachtoffers van kernongevallen", Nederlands Juristenblad, 1986, p. 1342-1345.

WILDHABER, Luzius, "Nuclear Plant on Borders and their Transboundary Impacts", in CrossBorder Relations: European and North American Perspectives, Ercmann, S. (Ed.), Zurich, 1987, Schulthess Verlag, p. 213-233. 